\title{
Guidelines Aimed at Reducing the Risks of User Acceptance Delay in the Context of an IT Service Project Management Plan
}

Eun Joo Jeong, Ji Hwan Bae, Seung Ryul Jeong

Graduate School of Business IT, Kookmin University, Seoul, Republic of Korea

\section{Article Info}

Article history:

Received Mar 10, 2015

Revised May 12, 2015

Accepted Jun 2, 2015

\section{Keyword:}

IT service project

Project management plan

Project risk management

Project success and failure

factors

User acceptance test

\begin{abstract}
Delays in the user acceptance of information technology (IT) service projects in Korea have occurred frequently due to various risk factors. User acceptance delays may hinder the achievement of the client's project objectives and cause schedule delays or cost overruns. Furthermore, the client may impose a delay charge and claim for additional damages, causing serious disputes between buyer and supplier. The main causes of user acceptance delays are unclear user requirements, changes in user requirements, poor-quality development outputs, excessive functional and non-functional errors, lack of user involvement, unclear user roles and responsibilities, and unclear criteria of user acceptance test.We help foster the timely completion of user acceptance by proposing a method of identifying the risk factors in user acceptance delay and creating a project management plan to weed out the identified risks. We propose a guideline for an IT service management plan that weeds out or lowers the risk factors well in advance. To validate the guideline's utility, we apply it to IT service projects. The results show that the guideline is effective in identifying and removing risk factors affecting delays in the user acceptance of IT service projects.
\end{abstract}

Copyright () 2015 Institute of Advanced Engineering and Science. All rights reserved.

\section{Corresponding Author:}

Seung Ryul Jeong, Graduate School of Business IT,

Kookmin University,

77 Jeongneung-ro, Seungbuk-gu, Seoul, Republic of Korea

Email: srjeong@kookmin.ac.kr

\section{INTRODUCTION}

User acceptance delays occur frequently in IT service projects in Korea due to various risks. User acceptance can be either intermediate or final [1]. Intermediate user acceptances execute at the end stages of project milestones, such as during system analysis and design, development, or integration and system test. Final user acceptance executes at the stage of project completion to confirm readiness for system operation. The results of user acceptance tests are closely related to project payments, which are made after the intermediate and final user acceptance tests have been passed. Delays in intermediate or final user acceptance tests may impede project objectives and impose additional costs in time and money [2]. The buyer may also impose delay charges on the supplier or go to court if the disputes cannot be resolved between them.

User acceptance delays carry critical risks, such as (categorized by project milestone) unclear user requirements during analysis and design, schedule delays and poor-quality program codes during development, an extension of the integration test period, changes to requirements during the integration test, and a lack of user involvement, and unclear final user acceptance test criteria during test. To ensure that user acceptance tests completed on time, we propose that the risk factors for user acceptance tests need to identify 
and that detailed procedures and criteria for preventing the identified risks in advance need to specify in the project management plan.

Most studies have discussed the failure and success factors in projects and user acceptance tests [310] as well as project management plan items. However, few studies on project management plans have discussed procedures and criteria for preventing the IT service project risks of user acceptance delays.

Chapter 2 provides some background for this study. Chapter 3 introduces the guidelines for the IT service management plan proposed in this study. Chapter 4 validates the proposed guidelines by applying them to IT service projects. In the last chapter, we discuss the results and limitations of this study as well as possibilities for future research.

\section{BACKGROUND KNOWLEDGE \\ 2.1. Project Management Plan}

A project management plan is a formal, approved document that defines how project activities are to be executed, monitored, controlled, and concluded. It typically comprises project baselines of scope, schedule, and cost and subsidiary management plans such as scope, time, cost, quality, human resources, communication, procurement, risk, stakeholders, and integration as well as other planning documents such as requirements and change management (see Table 1). The contents of project management plans vary depending upon the application area and complexity of the project [11]. Project management plans are very important because they are kind of contract documentations and become a baseline for project activities and execution. If any serious disputes between the supplier and buyer arise, the project management plan becomes a reference for decision-making or assessment of disputes. Therefore, project management plans need to write clearly and concretely in line with the guidelines. Management plans for software projects have the following major sections: overview, project organization, managerial process plan, technical process plan, and support process plan (see Table 2).

Table 1. Sections of project management plan [11]

\begin{tabular}{ll}
\hline Major Section & Section Topics \\
\hline Project baselines & Scope baseline, Schedule baseline, Cost baseline, Project baselines management \\
Subsidiary plans & Management plans(Scope, Cost, Schedule, Requirements, Quality, Risk, Process \\
& $\begin{array}{l}\text { improvement, Human resource, Procurement, Communications, Stakeholders) } \\
\text { Others }\end{array}$ \\
& $\begin{array}{l}\text { Life cycle; Project objectives; Other Management Plans (Change, Issues, Process, } \\
\text { Configuration) }\end{array}$ \\
\hline
\end{tabular}

Table 2. Management plan for software projects [12]

\begin{tabular}{ll}
\hline Major Section & Section Topics \\
\hline Overview & $\begin{array}{l}\text { Purpose, scope, objectives; Assumptions and constraints; Project deliverables; Schedule and } \\
\text { budget summary; Evolution of the plan }\end{array}$ \\
$\begin{array}{l}\text { Project organization } \\
\text { Managerial process plan }\end{array}$ & $\begin{array}{l}\text { External interface; Roles and responsibilities; Internal structure } \\
\text { Work plan(work activities, schedule, resource, and budget allocation); Control plan; }\end{array}$ \\
& $\begin{array}{l}\text { Risk management plan; Closeout plan } \\
\text { Technical process plan } \\
\text { Supporting process }\end{array}$ \\
$\begin{array}{l}\text { plan } \\
\text { Process model; Methods, tools, and techniques; Infrastructure plan; Product acceptance plan } \\
\text { Configuration management plan; Verification and validation plan; Documentation plan; } \\
\text { Quality assurance plan; Reviews and audits; Problem resolution plan; Subcontractor } \\
\text { management plan; Process improvement plan }\end{array}$ \\
\hline
\end{tabular}

\subsection{Characteristics of IT Service Project}

Enterprises have recently increased their IT service projects, providing integrated information systems as required by their clients, to achieve their business goals. In an IT service project, project team members conduct strategic planning, analyze user requirements, design the IT system based on the user requirements, develop and test the integrated information system using hardware and software, and operate and optimize the integrated information system. An IT service project creates new services that integrate IT professional technologies with industrial knowledge to upgrade an organization's competitiveness and improve its value and products using IT skills [13]. Thus, members of IT service project teams require IT professional technologies, industrial knowledge, and the skills needed to manage project factors such as scope, schedule, cost, and risk. Project team members gather and analyze the users' business requirements 
and the system's functional and non-functional requirements during the analysis phase.The requirements of the users and the system might be unclear due to invisible software characteristics. During the system integration test, moreover, user requirements are often changed. These changes may affect system quality, delay the schedule of system integration test, cause cost overruns, and delay the user acceptance test. In Korea, suppliers and buyers sign contracts using firm-fixed prices and a turnkey for IT service project agreements [14]. In a turnkey contract, the supplier undertakes to deliver the systems the user requires on time, and the buyer is obliged to pay the supplier depending on the results of the user acceptance test (see Figure 1).

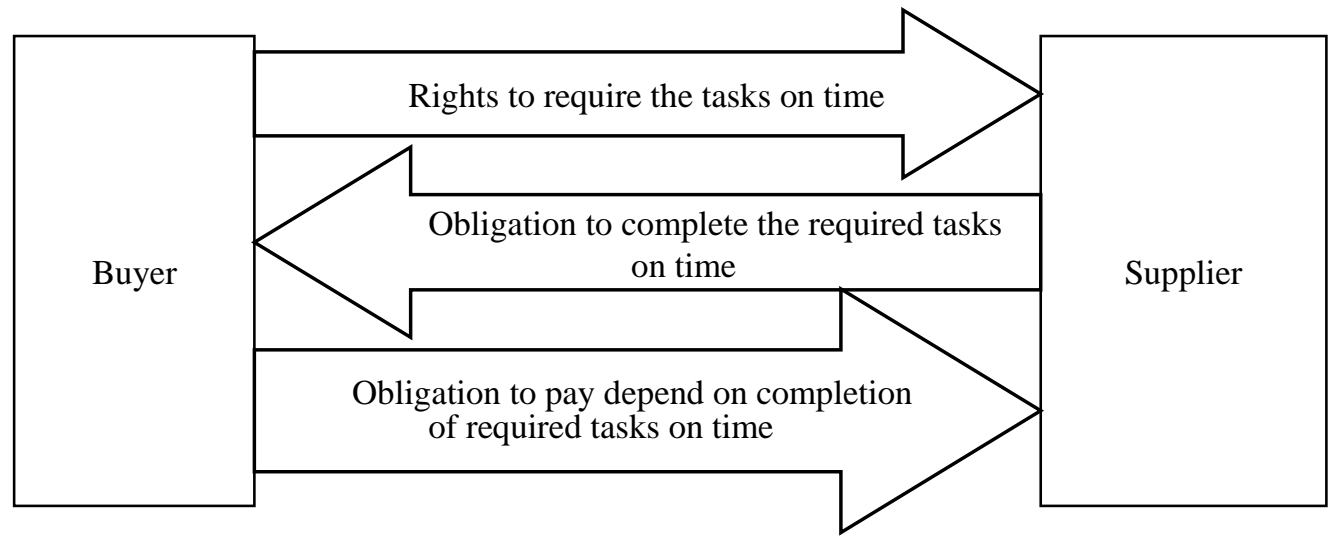

Figure 1. Rights and obligation of turnkey type contract [1]

Payments for IT service projects will pay when the tasks required for project milestones are completed. Sample payments divide into five installments, each with its own schedule and criteria. Payment percentage rates depend on the degree of project completion (see Table 3).

Table 3. Sample payments schedule and criteria [15]

\begin{tabular}{|c|c|c|c|}
\hline Payments & Rate (\%) & Schedule & Criteria \\
\hline Initial & 20 & Agreement of contract & Issue contract performance bond \\
\hline $1^{\text {st }}$ Middle & 15 & Completion of analysis and design & Pass criteria of design completion \\
\hline $2^{\text {nd }}$ Middle & 20 & Completion of program development & Pass criteria of unit test of program code \\
\hline $3^{\text {rd }}$ Middle & 15 & Completion ofintegration test & Pass criteria of integration test \\
\hline Final & 30 & Completion of final user acceptance test & $\begin{array}{l}\text { Pass criteria of system openness and } \\
\text { optimization }\end{array}$ \\
\hline
\end{tabular}

\subsection{Failure and Success Factors for Projects}

The Standish Group Report lists the top 10 failure and success factors for projects. The main factors relate to requirements, user involvement, and the project plan (see Table 4). To ensure that user acceptance tests execute on time, project team members should write the project management plan clearly and concretely to prevent project failure and address the risk factors related to requirements and project planning.

Table 4. Project failure and success factors [16]

\begin{tabular}{llll}
\hline Failure factors & $\%$ & Success factors & \\
\hline Incomplete requirements & 13.1 & User involvement & 15.9 \\
Lack of user involvement & 12.4 & Executive and management support & 13.9 \\
Lack of resources & 10.6 & Clear statement of requirements & 13.0 \\
Unrealistic expectations & 9.9 & Proper project planning & 9.6 \\
Lack of executive support & 9.3 & Realistic expectations & 8.2 \\
Changing requirements and specifications & 8.7 & Smaller project milestones & 7.7 \\
Lack of project planning & 8.1 & Competent staff & 7.2 \\
Didn't need it any longer & 7.5 & Ownership & 5.3 \\
Lack of IT management & 6.2 & Clear vision and objectives & 2.9 \\
Technological illiteracy & 4.3 & Hard-working, focused staff & 2.4 \\
\hline
\end{tabular}


Tarawneh (2011) categorized software project success and failure factors into organizational, technical, people, and culture groups (see Table 5) [17] and each factor have detail variables and made rank. I added the knowledge areas of project management to each variable of success and failure factors. The major knowledge areas of project management related to success and failure factors are quality, stakeholder, scope, time and cost, and human resource. Widerman (1992) classifies the project risks according to their impact on the project (see Table 6) [19]. He categorizes the project risks by project knowledge areas as like scope, quality, schedule and cost.

Table 5. Factors in software success and failure [17][18]

\begin{tabular}{|c|c|c|c|}
\hline Factors & Variables & Rank & PM Knowledge Areas \\
\hline \multirow[t]{4}{*}{ Organizational } & Formal methodology & 7 & Quality \\
\hline & Clear business objectives & 4 & Stakeholder \\
\hline & Executive support & 3 & Stakeholder \\
\hline & Minimized project scope & 5 & Scope \\
\hline \multirow[t]{3}{*}{ Technical } & $\begin{array}{l}\text { Understanding requirements \& management } \\
\text { requirement changes }\end{array}$ & 1 & Scope \\
\hline & Standard software infrastructure & 8 & Scope \\
\hline & Reliable estimate & 6 & Time and Cost \\
\hline \multirow[t]{2}{*}{ People } & User involvement & 2 & Stakeholder \\
\hline & Experienced project manager & 9 & Human Resource \\
\hline Culture & Organizational culture & 10 & Stakeholder \\
\hline
\end{tabular}

Table 6. Project risks [19]

\begin{tabular}{ll}
\hline PM Areas & Risks \\
\hline Scope & Changes of scope or the subsequent need for fixes to achieve the required technical deliverables \\
Quality & Failure to complete tasks to the required level of technical or quality performance \\
Schedule & $\begin{array}{l}\text { Failure to complete tasks within the estimated time limits or risks associated with dependency network } \\
\text { logic }\end{array}$ \\
Cost & Failure to complete tasks within the estimated budget allowances \\
\hline
\end{tabular}

\section{GUIDELINES FOR PROJECT MANAGEMENTPLAN OF IT SERVICE}

We create guidelines for project management plans of IT service by identifying the objectives and criteria, and identify the delay factors of user acceptance in the software development life cycle. Then, we suggest guidelines for eliminating the delay factors and apply them to actual projects (see Figure 2).

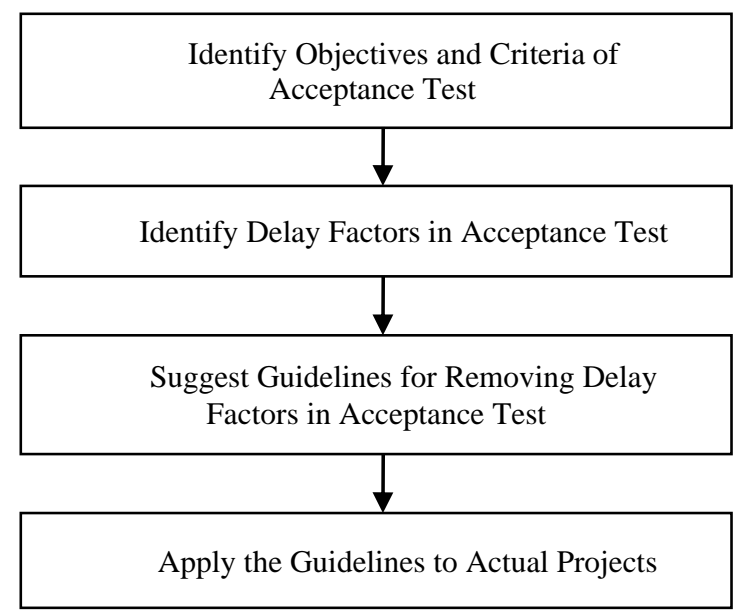

Figure 2. Procudure of making guidelines [15]

\subsection{User Acceptance Test Criteria}

Hareton (1997) notes that software testing consists of the following phases: unit test, integration test, system test, user acceptance test (UAT), and test objectives and criteria for each software test phase [20]. Klein (2003) notes that the "software system test is the validation that the software meets its requirement" 
and that "acceptance testing checks the system behavior against the customer's requirements (the 'contract')" [21]. Hareton (1997) notes, "the user acceptance test is an important step as the last line of verification to check the readiness of a software deliverable against the user's expectation” [20]. The objectives and criteria of user acceptance tests in the IT service project lifecycle shown in Table 7. Intermediate user acceptance tests occur during the analysis, design, and test stages, and the final user acceptance test occurs in the acceptance test stage. The criteria of the user acceptance test comprise the quality attributes of the requirement specification, the system quality attributes, the software quality attributes, the functional and non-functional system requirements, and the readiness of system operation [22][23].

Table 7. User acceptance criteria [22][24]

\begin{tabular}{lll}
\hline Stage & Acceptance Objective & Acceptance Criteria \\
\hline Analysis & Requirements specification, & Quality attributes of requirement specification \\
& ER(Entity Relation) Diagram & \\
Design & System architecture & System quality attributes \\
Development & Program specification, Source code & Software quality attributes, \\
& Results of unit test & Component quality attributes \\
Integration Test & Results of integration/system test & Functional \& non-functional requirements \\
System test & Results of system test & System quality \\
Acceptance test & Results of acceptance test & Readiness of system operation \\
\hline
\end{tabular}

\subsection{Delay Factors for User Acceptance Test}

This research suggests that the major delay factors in user acceptance tests relate to scope, time, quality, and stakeholder management (see Table 8). Nidumolu (1996) notes, "Requirements uncertainty had a significant effect on residual performance risk and a direct negative effect on process performance" [25]. User involvement is appropriate for solving unstructured problems when user acceptance is important [26][3]. Scope management addresses changes in scope and inrequirements (including clarifications). Time management addresses lack of schedule management skills and short or unrealistic project periods. Quality management addresses unclear integration test criteria, excessive functional and non-functional system errors, and poor-quality deliverables. Stakeholder management addresses lack of user involvement in requirements definition, unclear definition of the user's role, and lack of user involvement during data migration, the integration test, and the user acceptance test. Human resource management addresses lack of system design and test competency and system optimization.

Table 8. User acceptance delay factors [15][27][28]

\begin{tabular}{lll}
\hline Stage & Acceptance test delay factors & PM Area \\
\hline Analysis & Lack of user involvement & Stakeholder \\
& Unclear requirement & Scope \\
Design & Lack of requirement definition, Requirement change/add & Scope \\
& Poor quality of design & Quality \\
Development & Delay in development and hardware installation & Time \\
& Poor quality of program code & Quality \\
Integration and system & Requirement change/add & Scope \\
test & Unclear criteria of test & Quality \\
& Lack of user involvement & Stakeholder \\
System openness & Functional Errors \& Performance issues & Quality \\
& Delay in data migration & Stakeholder \\
Acceptance Test & Poor quality of data migration, Lack of operation readiness & Quality \\
\hline
\end{tabular}

\subsection{Guidelines for IT Service Project Management Plan}

We create detailed guidelines for IT service project management plans according to several knowledge areas: time, scope, quality, and human resource and stakeholder management (see Table 9). Each knowledge area contains several items. Time management includes project period and milestone. Scope management includes target system configuration and details on work performed, hardware and software lists to deliver, change management criteria and procedures, baseline schedule for requirement and design, and freezing schedule for system changes. Quality management includes methodology, quality objectives and assurance, user acceptance criteria and procedures, and project completion procedures. Stakeholder management includes project execution organization, user roles and responsibilities, and user involvement in developing user requirements on time. 
Table 9. Guidelines for IT service project management plan [11][12][20][27]

\begin{tabular}{|c|c|c|c|}
\hline $\begin{array}{l}\text { PM } \\
\text { Areas }\end{array}$ & Item & $\begin{array}{l}\text { Related to } \\
\text { Acceptance Test }\end{array}$ & Guidelines for IT Service Project Management Plan \\
\hline \multirow[t]{2}{*}{ Time } & Period & $\begin{array}{l}\text { Final acceptance } \\
\text { test date }\end{array}$ & $\begin{array}{l}\text { Project period must align with contract period, covering start to end } \\
\text { using the YYYYMMDD format, including the optimization period. }\end{array}$ \\
\hline & $\begin{array}{l}\text { Detailed } \\
\text { Schedule }\end{array}$ & $\begin{array}{l}\text { Intermediate } \\
\text { acceptance } \\
\text { test date }\end{array}$ & $\begin{array}{l}\text { Detailed project schedule must align with project period and milestones } \\
\text { and with other project management areas (e.g., scope, quality, risk). }\end{array}$ \\
\hline \multirow[t]{3}{*}{ Scope } & $\begin{array}{l}\text { Scope of } \\
\text { Project }\end{array}$ & $\begin{array}{l}\text { Scope of final } \\
\text { acceptance } \\
\text { test }\end{array}$ & $\begin{array}{l}\text { Project scope must cover entire system configuration. Skilled } \\
\text { specialists should review configurations of business application, system } \\
\text { including hardware and software for project. }\end{array}$ \\
\hline & $\begin{array}{l}\text { Project } \\
\text { Work }\end{array}$ & $\begin{array}{l}\text { Scope of } \\
\text { intermediate } \\
\text { acceptance } \\
\text { test }\end{array}$ & $\begin{array}{l}\text { Project activities need to detail based on SOW or proposal. Project } \\
\text { work need to break down based on the WBS guidelines. Assumptions } \\
\text { and constraints of project work need to specify. Any changes during } \\
\text { negotiation stage need to reflect clearly. }\end{array}$ \\
\hline & $\begin{array}{l}\text { Hardware, } \\
\text { Software } \\
\text { Solutions }\end{array}$ & $\begin{array}{l}\text { Scope of } \\
\text { acceptance test } \\
\text { for hardware and } \\
\text { software solutions }\end{array}$ & $\begin{array}{l}\text { Hardware installation schedule and warranty start date need to write } \\
\text { clearly. If customers supply the hardware and/or software solutions, the } \\
\text { customer's role in supply and delivery schedule of hardware and } \\
\text { software need to write clearly. }\end{array}$ \\
\hline \multirow[t]{4}{*}{ Quality } & Methodology & $\begin{array}{l}\text { Deliverables for } \\
\text { acceptance test }\end{array}$ & $\begin{array}{l}\text { Methodologies for development and solutions need to customize } \\
\text { properly. Outputs and deliverables of each stage need tooptimize and } \\
\text { align with user acceptance tests schedule. }\end{array}$ \\
\hline & $\begin{array}{l}\text { Quality } \\
\text { Criteria }\end{array}$ & $\begin{array}{l}\text { Criteria of } \\
\text { acceptance test }\end{array}$ & $\begin{array}{l}\text { Quality criteria of user acceptance test should be measurable and } \\
\text { realistic. }\end{array}$ \\
\hline & $\begin{array}{l}\text { Acceptance } \\
\text { Test }\end{array}$ & $\begin{array}{l}\text { Procedures of } \\
\text { acceptance test }\end{array}$ & $\begin{array}{l}\text { Procedures of intermediate and final user acceptance test need to write } \\
\text { clearly (e.g., type, schedule, test criteria). }\end{array}$ \\
\hline & Completion & $\begin{array}{l}\text { Criteria of final } \\
\text { acceptance test }\end{array}$ & $\begin{array}{l}\text { Completion process and criteria of project and system delivery need } \\
\text { todefine clearly. }\end{array}$ \\
\hline \multirow[t]{2}{*}{$\begin{array}{l}\text { Stake } \\
\text { holder }\end{array}$} & $\begin{array}{l}\text { Roles and } \\
\text { Responsibilitie } \\
\text { s of }\end{array}$ & User involvement & $\begin{array}{l}\text { Roles and responsibilitiesof clients and users need to define clearly to } \\
\text { develop business and user requirements on time. Roles of clients and } \\
\text { users need to define for user acceptances test. }\end{array}$ \\
\hline & Organization & $\begin{array}{l}\text { Executive and } \\
\text { management } \\
\text { support }\end{array}$ & $\begin{array}{l}\text { Organization charts of project teams, including clients, need to include } \\
\text { all of subsystem and functional departments, including steering } \\
\text { committee and PMO. Roles and responsibilities of each project team } \\
\text { and functional departments need to write clearly. }\end{array}$ \\
\hline \multirow[t]{3}{*}{$\begin{array}{l}\text { Integra } \\
\text { tion }\end{array}$} & Change & Scope change & $\begin{array}{l}\text { Objectives, procedures, and criteria of change requests need to write } \\
\text { clearly. Change categories and classes must align with project attributes } \\
\text { (e.g., scale, areas). }\end{array}$ \\
\hline & Baseline & Scope baseline & $\begin{array}{l}\text { Baseline schedule of user requirements and system design need to write } \\
\text { clearly. }\end{array}$ \\
\hline & Freezing & Freezing of change & $\begin{array}{l}\text { Freezing schedule of change requests for As-Is and To-Be system need } \\
\text { to write clearly. }\end{array}$ \\
\hline
\end{tabular}

* SOW(Statement Of Work), WBS(Work Breakdown Structure), PMO(Project Management Office)

\section{APPLICATION OF GUIDELINES FOR IT SERVICE PROJECT MANAGEMENT PLAN}

The enterprise PMO (Program Management Office) supplies the guidelines and templates of the project management plan to the project manager, who then drafts a version of the plan based on the guidelines and templates. The project manager then sends it to the enterprise PMO for review. The enterprise PMO suggests changes or passes it along. Meanwhile, the project manager adjusts the draft's contents during discussions with clients. After they come to a mutual agreement on the plan, they set a baseline for it. The plan's guidelines need to standardize for enterprise-wide application. Nidumolu (1996) notes that "Increases in the standardization were directly associated with decreases in the residual performance risk which led to increase in both process and product performance" [25]. If it lacks standardized guidelines, the project management plan's effectiveness may vary depending on the project manager's competence or experience. In addition, critical contents concerning the user acceptance test might be missing or inaccurate. Any issues or disputes related to user acceptance may seriously affect the supplier through delays in the project or payment schedule. Project management plansare contracts and become the baseline for project activities and execution. The plan serves as the reference for decision-making and assessment during any serious dispute between supplier and buyer. Therefore, the plan must be clear, realistic, and detailed in line with the guidelines. We recommend using the procedure described belowto apply the guidelines enterprise-wide to address the risks of the user acceptance test (see Figure 3). 


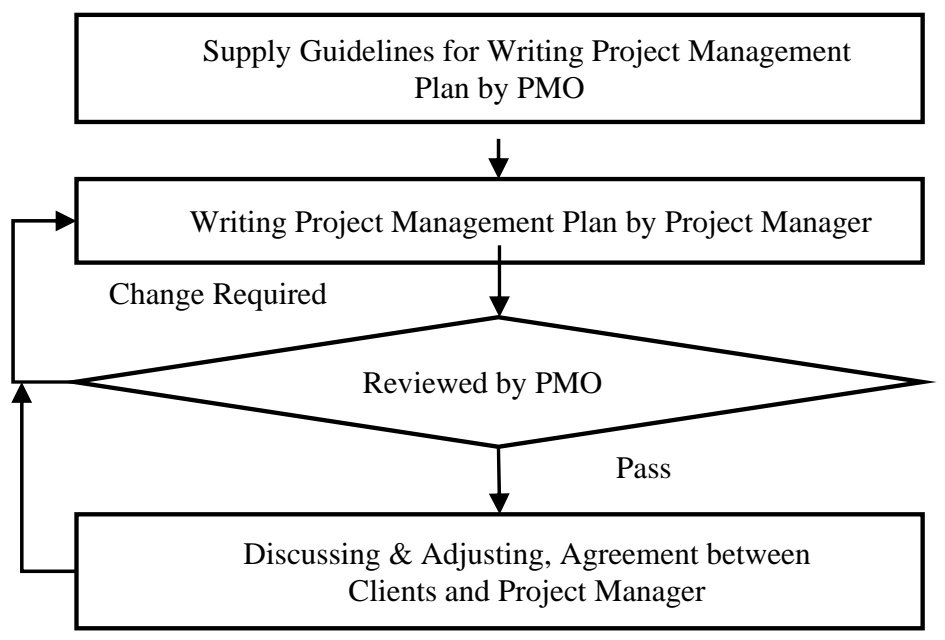

Figure 3. Application procedures of guideline [15]

We tried to apply the guideline to several actual projects as like large-scale new banking system and security system, and insurance system development projects. The risks related with user acceptance test can be weed out or lowered. In addition, the project management team can set the baseline for user requirement specification on time and trace and assess the requirement changes to impact quality of system, project period, and cost. Moreover, they make additional contract for contract amount increasing due to requirements changes [15].

\section{CONCLUSION}

Most IT service projects contracted through turnkey agreements, in which the scheduling of the middle and final payments depends on the results of the user acceptance test. If the test delays, the project also delay and cause cost overruns due to the additional resources required. Furthermore, the buyer can impose a delay charge and claim for any damages due to lost business opportunities.

This study sought to identify and remove the user acceptance test's risk factors that appear during project planning. We studied the objectives, items, and criteria of the user acceptance test and identified the delay factors emerging in the project lifecycle. We then created and applied detailed guidelines for a project management plan of IT service. The results showed that the project delay factors in the user acceptance test relating to tight scope management, change, quality, human resources, and stakeholders were reduced. As a baseline, for instance, effective requirement definition and tracing of requirement change can reduce the risk of schedule delays and cost overruns.

These guidelines for project management plans of IT service should help project managers, PMOs, and quality managers write and review their plans to facilitate timely completion of user acceptance test. However, this study is limited in being confined to IT service projects based on turnkey agreements. These guidelines need to apply to projects in other industries, such as construction and shipbuilding, and that are based on different contract types.

\section{REFERENCES}

[1] Act on Contracts to which the state is a party, Ministry of strategy and finance, Republic of Korea, 2012.

[2] K.B. Lee, et.al., "A Study on the Influencing factors on the Profit Improvement Rate of IT Service Projects", The Korea Society of Management Information System”, pp. 262-286, 2010.

[3] B. Ives, M.H. Olson, “USER INVOLVEMENT AND MIS SUCCESS: A REVIEW OF RESEARCH”, Management Science, vol. 30, no. 5, 1984, pp. 586-603.

[4] O. Zwikael, et.al., "From Critical Success Factors to Critical Success Processes", International Journal of Production Research, vol. 44, no. 17, 2006, pp. 3433-3449.

[5] D.I. Cleland, et al., Systems Analysis and Project Management, McGraw Hill, 1983.

[6] R.G. Cooper, et.al., "Benchmarking the firm's critical success factors in new product development”, Journal of Production of Innovation Management, vol. 12, 1995, pp. 374-391.

[7] J. Johnson, et al., “Collaborating on project success”, Software Magazine, 2001.

[8] P.W. Morris, et.al., The Anatomy of Major Projects, John Wiley and Sons, 1987.

[9] J.R. Turner, The Handbook of Project-based Management: Improving the processes for Achieving Strategic Objectives, McGraw-Hill, 1999.

Guidelines Aimed at Reducing the Risks of User Acceptance Delay in the Context of ...(Seung Ryul Jeong) 
[10] J.K. Pinto, et.al., “Critical factors in successful project implementation”, IEEE Transaction of Engineering Management, EM-34, 1987, pp. 22-27.

[11] PMI Standard Committee, A Guide to the Project Management Body of Knowledge $5^{\text {th }}$ Edition, Project Management Institute, 2013.

[12] K. Schwalbe, Information Technology Project Management 7th, Course Technology, 2013.

[13] Understanding of IT Service Industry, Korea Information Technology Service Industry Association, 2013.

[14] H.S. Kim, “An Improvement of SI Contracting Laws and Regulations in Korea”, Korea Society of IT Services, vol. 1, no. 1, 2013, pp. 29-43.

[15] Internal Project Report, “A” IT service Company, 2013.

[16] The Standish Group Report, 2010, the Standish Group.

[17] H. Tarawneh, “A Suggested Theoretical Framework for Software Project Success”, Journal of software Engineering and Application, vol. 4, 2011, pp. 646-651.

[18] D.B. Khang, et.al., "Success Criteria and Factors for International Development Projects: A life Cycle Based Framework”, Project Management Journal, vol. 39, no. 1, 2008, pp. 72-84.

[19] R. Max Widerman, Project \& Program Risk Management, A guide to managing project risks and opportunities, Project Management Institute, 1992, p. III-3.

[20] K.N. Leung Hareton, et.al., “A study of user acceptance tests”, Software Quality Journal v. 6, pp. 137, 1997.

[21] C.S. Klein, “LIMS USER ACCEPTANCE TESTING”, Quality Assurance, vol. 10, 2003, pp. 91-106.

[22] S.Y. Ryu, System Analysis and Requirement Engineering, Hanti Media, 2013.

[23] E. Hull, et.al., Requirements Engineering, Springer-Verlag, London, 2002.

[24] I. Sommerville, Software Engineering, Addison Wesley, 2006.

[25] S.R. Nidumolu, "Standardization, requirements uncertainty and software project performance", Information \& Management, vol. 31, 1996, pp. 135-150.

[26] R. Palanisamy, "Empirically Testing the Relationships between User Involvement, Information Waste, and MIS Success”, Journal of Services Research, vol. 1, 2001, pp. 70-103.

[27] W.I. Kwon, et.al., Practical Software Testing Foundation, Software Testing Alliances, 2006.

[28] B.P. Lientz, et.al., Risk Management for IT Projects, BH, 2006.

\section{BIOGRAPHIES OF AUTHORS}

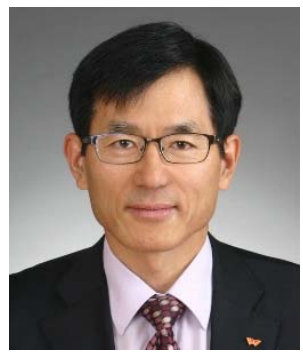

Eun Joo Jeong is currently a Ph. D. candidate in the Graduate School of Business IT at Kookmin University, Korea. He obtained a B.S. in Electronics Engeineering at Chosun University and an M.A. in MIS at Yonsei University, Korea. Mr. Jeong has over 30 years of industry experiences in the areas of IT Project Management, IT Audit, and Contract Management. He has published several papers in the proceedings and journals including Journal of Internet Computing and Services.

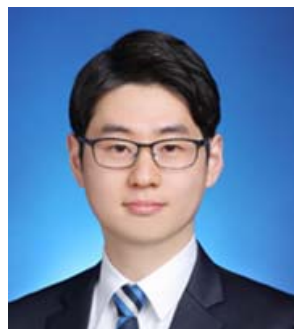

Ji Hwan Bae is currently pursuing Master's degree in the Graduate School of Business IT at Kookmin University, Korea. He holds a B.S. in Computer Science from Suwon University, Korea. Mr. Bae's research interests include Enterprise Architecture, Information Systems Planning, and Project Management.

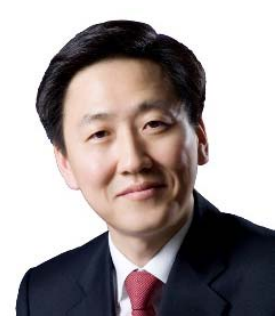

Seung Ryul Jeong is a Professor in the Graduate School of Business IT at Kookmin University, Korea. He holds a B.A. in Economics from Sogang University, Korea, an M.S. in MIS from University of Wisconsin, and a Ph.D. in MIS from the University of South Carolina, U.S.A. Professor Jeong has published extensively in the information systems field, with over 60 publications in refereed journals like Journal of MIS, Communications of the ACM, Information and Management, Journal of Systems and Software, among others. 